\title{
Raised levels of an unknown beta globulin in the serum of patients with non-specific urethritis and Reiter's disease
}

\author{
G. W. CSONKA*, E. W. BASSETT†, AND G. FURNESS † \\ From the Central Middlesex Hospital, London ${ }^{\star}$, and the College of Medicine and Dentistry of New fersey†, \\ Department of Microbiology, New fersey Medical School, Newark, New fersey 07103, U.S.A.
}

Besides infection with T-mycoplasmas (Shepard, 1970), Chlamydia (Dunlop, Vaughan-Jackson, and Darougar, 1972; Oriel, Reeve, Powis, Miller, and Nicol, 1972), and Corynebacteria (Furness and Csonka, 1966; Furness, Kamat, Kaminski, and Seebode, 1971), hypersensitivity of the mucosa of the male urethra to antigens in the vaginal secretions of the female consort has been postulated as the mechanism of non-specific urethritis (NSU) (Weston, 1965). Precipitin tests show reactions not only between the urethral discharge of the patient and his consort's serum but also between the consort's vaginal secretions and the patient's serum. These cross-reactions indicate that the same antigens and antibodies are present in both partners. Precipitating antibodies suggest an infectious ætiology rather than either immediate or delayed hypersensitivity which usually can be detected only by skin tests.

The immunoglobulins in the sera of normal subjects and of patients with NSU or gonorrhoea have also been compared by means of precipitin tests (Scott and Rasbridge, 1972). The mean levels of IgM, IgG, and IgA are significantly higher in patients than in controls, but the differences are not sufficiently consistent to be of diagnostic value. However, the similarity of the antibody changes in patients with gonorrhoea and in those with NSU suggests that the latter is also due to an infection.

Bacterial infections not only stimulate the production of gamma globulins but are also responsible for elevated levels of alpha and beta globulins in human sera. Therefore, a comparison has been made of chromatograms of the proteins in the sera of normal subjects and of patients with either nonspecific urethritis, gonococcal urethritis, or Reiter's disease. The results are reported in this paper.

\begin{abstract}
Material and methods
Only white male patients whose clinical histories were known personally to the investigators were selected for this study. The patients with gonorrhoea had not suffered from NSU or Reiter's disease and had acute infections which were confirmed in the laboratory; they did not develop post-gonococcal urethritis. Ph.D. students and technicians volunteered as controls. The controls and patients with gonorrhoea, NSU, and Reiter's disease were in a similar age group of 22 to 36 years.
\end{abstract}

\section{ANTISERA}

The specific hyperimmune antisera to human alpha $\mathrm{a}_{1}$, acid glycoprotein, haptoglobulin, and antitrypsin were available commercially (Behring Diagnostics, Somerville, New Jersey). The techniques recommended by Williams and Chase (1967) for the production of antisera to sera and serum fractions were employed. The antiserum to human serum was obtained by repeatedly injecting rabbits intravenously with pooled normal human sera while antisera to human urine was prepared as follows: Normal urine was dialysed against water and centrifuged. Then, the supernatant was decanted and lyophilized. The lyophilized urine powder was dissolved in a minimal volume of physiological saline and emulsified in Freund's complete adjuvant. Each rabbit received two subcutaneous injections of the emulsion 6 weeks apart. Each injection contained approximately $2 \mathrm{mg}$. urine powder.

\section{COLUMN CHROMATOGRAPHY}

The sera were fractionated by gel filtration through $1.6 \times 100 \mathrm{~cm}$. columns of Sephadex G 200 (Pharmacia Fine Chemicals, Inc. Piscataway, New Jersey), which were equilibrated with sodium phosphate buffered saline $\mathrm{pH} 7 \cdot 2$ The buffer was passed upwards through the columns by means of a peristaltic pump with an upward flow rate of $12 \mathrm{ml}$./ $\mathrm{hr}$. Samples of $0.5 \mathrm{ml}$. serum were applied to the columns through the buffer lines and eluted with equilibrating buffer, the effluent being collected in $4 \mathrm{ml}$. fractions. During elution, an absorbance tracing was obtained by monitoring the effluent transmittance of ultraviolet light at $2,800 \AA$ by means of a Unicord II Model 8,300 \& (LKB). 
SERUM PROTEINS

When the elution profile indicated that a patient's serum had an elevated albumin peak, the $4 \mathrm{ml}$. fractions containing the albumin were pooled. Thereafter, the pools obtained from patients with either NSU or Reiter's disease were combined separately and concentrated by pressure dialysis on a Diaflow membrane (PM 10 Americon) which retained substances over $M W 10,000$. The concentrate was adjusted to pH 5.8 with acetic acid, 40 per cent. ethanol added, and kept overnight at $5^{\circ} \mathrm{C}$. to precipitate the albumin (Schmid, 1950). The precipitate was sedimented by centrifugation at $4,000 \mathrm{G}$, the supernatant decanted into a dialysing bag and the ethanol removed by dialysis against water. The serum globulins were then concentrated by pressure dialysis.

In order to standardize the serum globulins, the optical density of an aliquot was measured at $2,800 \AA$ on a Beckman DBGT spectrophotometer and the protein content calculated as human serum albumin (Cohn, Strong, Hughes, Mulford, Ashworth, Melin, and Taylor, 1946). Thereafter the protein solutions were standardized to contain approximately $50 \mathrm{mg} . / \mathrm{ml}$. protein.

POLYACRYLAMIDE GEL ELECTROPHORESIS

To adjust the $\mathrm{pH}$, the protein solution was dialysed against several changes of Tris glycine buffer $\mathrm{pH} 8.5$. Then the alpha and beta globulins were separated on 7.5 per cent. polyacrylamide gels by means of the techniques recommended for use with the Model 1200 Canalco Research Disc Electrophoresis apparatus (Canalco, Rockville, Maryland).

\section{IMMUNODIFFUSION}

For double diffusion, thin agar plates were prepared by pouring into $9 \mathrm{~cm}$. Petri dishes $6 \mathrm{ml}$. of 1 per cent. Noble

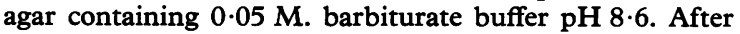
the wells were cut in the agar by means of a template, they were filled with the reagents and left at room temperature. Optimal precipitation occurred within 24 to $48 \mathrm{hrs}$.

\section{Results}

The elution profiles of the sera from ten controls and from ten patients with gonorrhoea had characteristic IgM (19S), IgG (7S), and albumin (5-3S) peaks (Fig. 1).

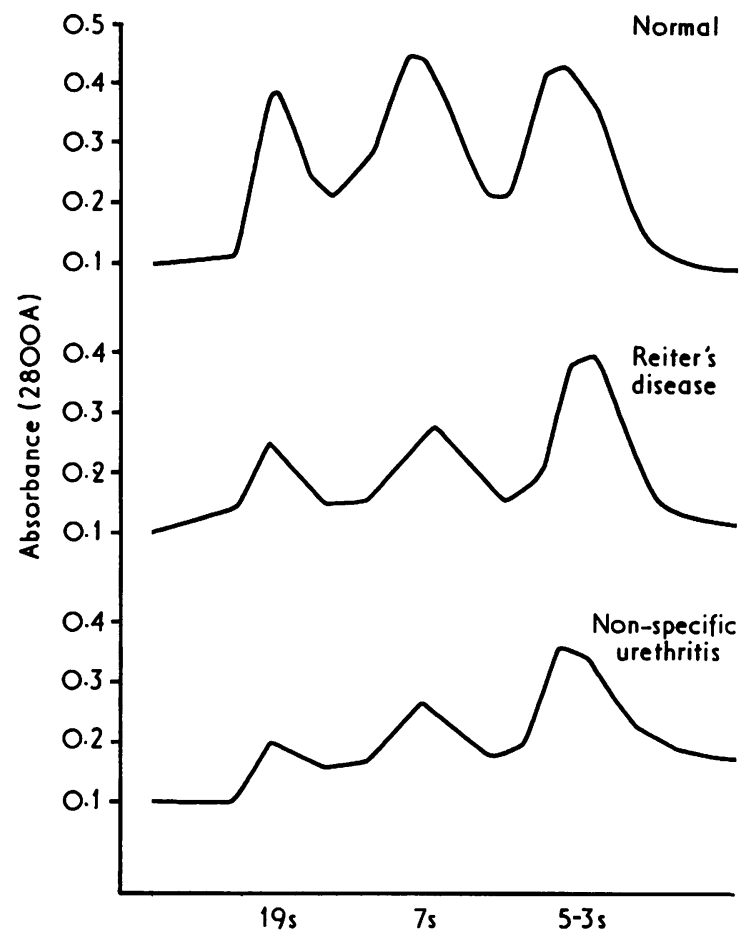

FIG. 1 Chromatogram. Raised albumin peak (5-3S) in sera of patients with NSU and Reiter's disease

With one exception the elution profiles of the sera of the ten NSU patients (Table I) showed normal IgM and IgG peaks but had elevated albumin peaks (Fig. 1). The exception was a patient who had recovered from his third episode and had a normal chromatogram (Table I).

The elution profiles of the sera from the ten patients with Reiter's disease varied (Table II), but the chromatograms with only elevated albumin peaks were

TABLE I Relationship of levels of serum proteins to clinical histories of patients with non-specific urethritis

\begin{tabular}{|c|c|c|c|c|c|c|}
\hline \multirow[b]{2}{*}{ Patient no. } & \multirow[b]{2}{*}{ Age (yrs) } & \multirow{2}{*}{$\begin{array}{l}\text { Number of } \\
\text { episodes }\end{array}$} & \multirow{2}{*}{$\begin{array}{l}\text { Interval between onset and } \\
\text { obtaining serum }\end{array}$} & \multicolumn{3}{|c|}{ Serum protein levels } \\
\hline & & & & $I g M$ & $I g G$ & Beta globulin \\
\hline $\begin{array}{r}7995 \\
9815 \\
1355 \\
1731 \\
4193 \\
6732 \\
3065 \\
357 \\
315 \\
1772\end{array}$ & $\begin{array}{l}23 \\
29 \\
28 \\
28 \\
22 \\
28 \\
30 \\
23 \\
27 \\
31\end{array}$ & $\begin{array}{l}1 \\
1 \\
3 \\
4 \\
5 \\
4 \\
11 \\
\text { Chronic } \\
\text { Chronic } \\
\text { Chronic }\end{array}$ & $\begin{array}{c}10 \text { days } \\
8 \text { wks } \\
4 \text { wks } \\
5 \text { days } \\
5 \text { days } \\
8 \text { wks } \\
10 \text { days } \\
1 \text { yr } \\
2 \text { yrs } \\
6 \text { yrs }\end{array}$ & $\begin{array}{l}\mathbf{N} \\
\mathbf{N} \\
\mathbf{N} \\
\mathbf{N} \\
\mathbf{N} \\
\mathbf{N} \\
\mathbf{N} \\
\mathbf{N} \\
\mathbf{N} \\
\mathbf{N}\end{array}$ & $\begin{array}{l}\mathbf{N} \\
\mathbf{N} \\
\mathbf{N} \\
\mathbf{N} \\
\mathbf{N} \\
\mathbf{N} \\
\mathbf{N} \\
\mathbf{N} \\
\mathbf{N} \\
\mathbf{N}\end{array}$ & $\begin{array}{l}E \\
E \\
N \\
E \\
E \\
E \\
E \\
E \\
E \\
E\end{array}$ \\
\hline
\end{tabular}

$\mathrm{N}=$ normal

$\mathbf{E}=$ elevated 
similar (Fig. 1) to those of the NSU patients. Even though the number of patients was few, it would appear that the level of IgM and albumin peaks was related to the stage of the disease. It can be inferred from these results that in an active condition, the IgM peak was usually higher than in the controls and this was followed by the appearance of an elevated albumin peak; thereafter, the IgM fell to a normal level. Moreover, the elution profiles of one convalescent patient and of another recovered patient were similar to those of the controls (Table II) suggesting that the albumin peak also could return to normal.

A definite increase in IgG was detected in only one patient and its significance is unknown.

In order to determine which serum constituent was responsible for the increased absorbance, the alpha and beta globulins in the 5-3S fractions from those NSU and Reiter's patients with elevated albumin peaks were separated by disc gel electrophoresis. The fractions from both NSU and Reiter's patients contained increased quantities of alpha $a_{1}$ acid glycoproteins, haptoglobulin, antitrypsin, and an unknown protein in the beta globulin region of the gels (Fig. 2).

On double diffusion of these pooled 5-3S fractions against antisera to human alpha ${ }_{1}$ acid glycoproteins, haptoglobulin, antitrypsin, human serum and urine, the unknown beta globulin reacted only with the antiserum to the human urine while the alpha globulins reacted with the antiserum to normal sera (Fig. 3, overleaf).

On double diffusion of unfractionated sera from four NSU patients $(9,815,3,065,357$ and 315see Table I) and from four with Reiter's disease $(9,726,8,390,7,435$ and 8,102-see Table II), they reacted similarly against antiserum to human urine.

\section{Discussion}

For this investigation to be meaningful it was imperative that the controls and the patients with

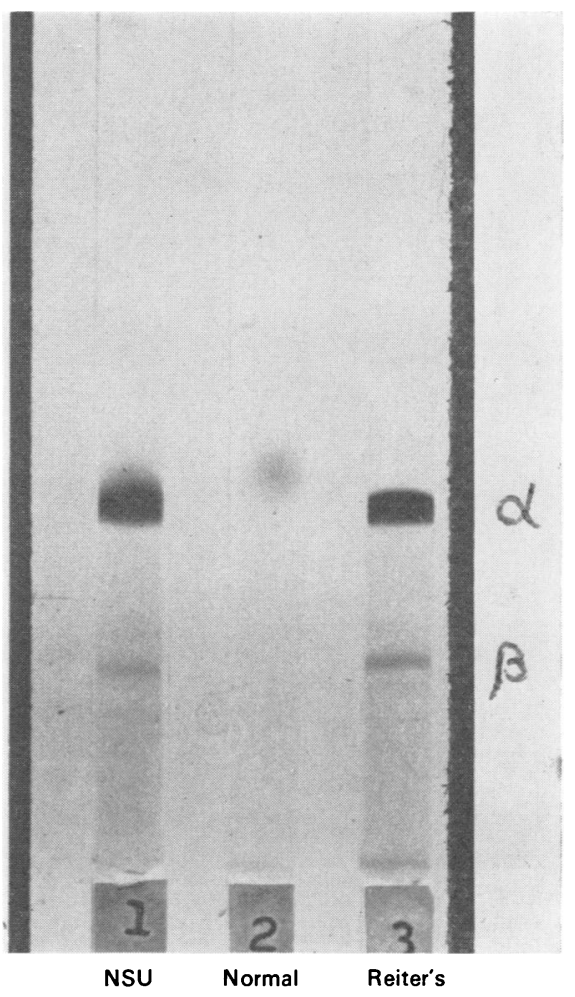

FIG. 2 Separation of globulins by polyacrylamide gel electrophoresis. Beta globulin absent in normal serum. (1) NSU (2) Normal (3) Reiter's disease

gonococcal urethritis and Reiter's disease had not suffered at any time from non-specific urethritis. Many patients are seen with gonorrhoea and NSU, but they are often individuals of a promiscuous disposition and their clinical histories cannot be verified. Only patients and controls who were known to the investigators were selected for this study, and in consequence their numbers are few.

TABLE II Relationship of levels of serum proteins to clinical histories of patients with Reiter's disease

\begin{tabular}{|c|c|c|c|c|c|c|c|c|}
\hline \multirow[b]{2}{*}{ Patient no. } & \multirow[b]{2}{*}{ Age (yrs) } & \multirow[b]{2}{*}{$\begin{array}{l}\text { No. of } \\
\text { episodes }\end{array}$} & \multirow[b]{2}{*}{ Severity } & \multirow{2}{*}{$\begin{array}{l}\text { Interval between } \\
\text { onset and obtaining } \\
\text { serum (wks) }\end{array}$} & \multirow[b]{2}{*}{ Phase of disease } & \multicolumn{3}{|c|}{ Serum protein level } \\
\hline & & & & & & $\operatorname{Ig} M$ & $I g G$ & $\begin{array}{l}\text { Beta } \\
\text { globulin }\end{array}$ \\
\hline 360 & 35 & 1 & Severe & 3 & Very active & $\mathbf{E}$ & $\mathbf{E}$ & $\mathbf{N}$ \\
\hline 7863 & 28 & 1 & Severe & 3 & Very active & $\mathbf{N}$ & $\mathbf{N}$ & $\mathbf{N}$ \\
\hline 7879 & 25 & 1 & Moderate & 12 & Active & $\mathrm{E}$ & $\mathbf{N}$ & $\mathbf{E}$ \\
\hline 9726 & 58 & 1 & Mild & 8 & Convalescent & $\bar{N}$ & $\mathbf{N}$ & $\mathbf{E}$ \\
\hline 8390 & 26 & $\overline{1}$ & Severe & 16 & Convalescent & $\mathbf{N}$ & $\mathbf{N}$ & $\overline{\mathbf{E}}$ \\
\hline 4288 & 48 & 1 & Mild & 68 & Recovered & $\mathrm{N}$ & $\mathrm{N}$ & $\mathbf{N}$ \\
\hline 7435 & 26 & 2 & Moderate & 8 & Active & $\mathbf{N}$ & $\mathbf{N}$ & $\mathbf{E}$ \\
\hline 8102 & 26 & 2 & Moderate & 12 & Improving & $\mathbf{N}$ & $\mathbf{N}$ & $\mathbf{E}$ \\
\hline 7873 & 25 & 3 & Moderate & 3 & Active & $\mathbf{E}$ & $\mathrm{N}$ & $\mathrm{E}$ \\
\hline 9464 & 30 & 5 & Mild & 12 & Convalescent & $N$ & $\mathbf{N}$ & $\mathbf{N}$ \\
\hline
\end{tabular}

$\mathrm{N}=$ normal

$\mathrm{E}=$ elevated 
FIG. 3 Alpha and beta globulins in fractionated sera from NSU and Reiter's patients separated by double diffusion. The beta globulin (line $\beta$ ) precipitated only with antisera to human urine; the alpha globulins (line $\alpha$ ) precipitated with antisera to normal human sera.

The wells contained: $U$-antiserum to human urine; $h$-antiserum to normal human sera;

No. 1 NSU and No. 2 Reiter's serum fractions containing the unknown $\beta$ globulin and the known a globulin

By themselves, elevated albumin peaks in elution profiles of the sera of the majority of the patients with either NSU or Reiter's disease might not be considered adequate evidence of these diseases. However, the finding that they contained an unknown beta globulin, which cannot be detected in the sera of normal individuals or in the sera from patients with gonococcal urethritis, suggests that these results are significant. As such, it seems reasonable to conclude that, even though the cause of these diseases is uncertain, the presence of this beta globulin in the sera of patients with clinical NSU and Reiter's disease indicates not only that the patient is suffering from one of these conditions but also that they are related.

There is no positive laboratory test to confirm a clinical diagnosis of NSU or Reiter's disease. This globulin appears to be a normal component of human urine and, if these findings are confirmed in an extended study which might also include the various forms of ankylosing spondylitis, it should not be difficult to prepare hyperimmune antiserum, specific for the beta globulin, thus enabling the precipitin test to be simplified for the rapid detection of this beta globulin in unfractionated serum. The elution profile indicated that the 5-3S region was not elevated in the serum of every patient. When it is known at what stages in the diseases the level of this globulin increases and then returns to normal, it should be possible to confirm a clinical diagnosis and to undertake epidemiological studies.

Moreover, if these diseases are of an infectious aetiology, the sera of infected consorts should contain this beta globulin and it should be possible to detect those who are carriers of the infectious agent.

\section{Summary}

An unknown beta globulin, which is a normal constituent of human urine and cannot be detected in the sera of normal subjects and of patients with gonococcal urethritis, is found in the sera of most patients with non-specific urethritis and Reiter's disease. Therefore, these conditions may be related. Moreover, its presence may prove a useful laboratory criterion for the confirmation of a clinical diagnosis of non-specific urethritis or Reiter's disease. 
We wish to thank Mr. Jack Whitescarver, M.S., and Mrs. Maria De Maggio Cioffi for their help. This investigation was supported in part by NIH research grant number R01 A108663 from the National Institute of Allergy and Infectious Diseases.

\section{References}

Cohn, E. J., Strong, L. E., Hughes, W. L., Mulford, D. J., Ashworth, J. N., MELIN, M., and TAYLOR, H. L. (1946) F. Amer. chem. Soc., 68, 459

Dunlop, E. M. C., Vaughan-Jackson, J. D., and Darougar, S. (1972) Brit. F. vener. Dis., 48, 424

FurNess, G., and CsonkA, G. W. (1966) Ibid., 42, 185

Kamat, M. H., Kaminski, Z., and Seebode, J. J. (1971) f. Urol. (Baltimore), 106, 557

Oriel, J. D., Reeve, P., Powis, P., Miller, A., and Nicol, C. S. (1972) Brit. F. vener. Dis., 48, 429

Schмid, K. (1950) f. Amer. chem. Soc., 72, 2816

ScotT, A. J., and RASBRIDGE, M. R. (1972) Brit. F. vener. Dis., 48, 133

Shepard, M. C. (1970) F. Amer. med. Ass., 211, 1335
Weston, T. E. T. (1965) Brit. F. vener. Dis., 41, 107 Williams, C. A., and Chase, M. W. (1967) 'Methods in Immunology and Immunochemistry', vol. 1 'Preparation of antigens and antibodies', 1st ed, p. 214. Academic Press, New York and London

Augmentation du taux d'une béta-globuline inconnue dans le sérum de malades atteints d'urétrite non spécifique et de maladie de Reiter

\section{SOMMAIRE}

Une béta-globuline inconnue, qui est un constituant normal de l'urine humaine et qui ne peut pas être détectée dans les sérums de sujets normaux ni dans ceux de malades atteints d'urétrite gonococcique, est trouvée dans les sérums de la plupart des malades atteints d'urétrite non spécifique et de maladie de Reiter. Les deux éléments peuvent donc être en relation. En outre, la présence de cette globuline peut apparaître comme un critère de laboratoire utile pour confirmer le diagnostic clinique d'urétrite non spécifique ou de maladie de Reiter. 